\title{
The Relationship between Job Stress, Job Performance and Job Motivation among Police Officers at the Federal Territory Police Headquarters
}

\author{
Kalaikumar Arujunan \\ Faculty of Educational Studies, Universiti Putra Malaysia \\ 43400 UPM Serdang, Selangor, Malaysia \\ Ismi Arif Ismail (Corresponding author) \\ Faculty of Educational Studies, Universiti Putra Malaysia \\ 43400 UPM Serdang, Selangor, Malaysia \\ Shamsuddin Othman \\ Faculty of Educational Studies, Universiti Putra Malaysia \\ 43400 UPM Serdang, Selangor, Malaysia \\ Mohd Mursyid Arshad \\ Faculty of Educational Studies, Universiti Putra Malaysia \\ 43400 UPM Serdang, Selangor, Malaysia
}

Received: Oct. 4, 2021 Accepted: Nov. 15, $2021 \quad$ Online published: Nov. 22, 2021

doi:10.5296/ijhrs.v11i4S.19236 URL: https://doi.org/10.5296/ijhrs.v11i4S.19236

\begin{abstract}
Job performance is an important aspect of employees which ensures the efficiency and effectiveness of an organization. Job performance is influenced by job stress, while job stress affects job motivation. Hence, this paper is intended to identify the relationship between these three variables among Royal Malaysia Police (PDRM) officers at the Federal Territory Police Headquarters. This is a quantitative study for which data has been collected from 341 police
\end{abstract}


officers through a survey. Data was analyzed statistically using PLS-SEM. Findings showed that there was a significant, negative relationship between job performance and job stress; and between job stress and job motivation.

Keywords: job performance, job stress, job motivation, royal Malaysia police

\section{Introduction}

\subsection{Research Background}

Studies on job performance have been extensively conducted before (Noermijati \& Primasari, 2015; Vijayan, 2017; Jamal, 2016). Job performance encompasses all activities performed in the execution of a particular job including the efficiency and outcomes of each behaviour (Chen, 2009). Employees who do not perform well in their job portray a negative image of an organization which in turn, affect its overall effectiveness. As such, job performance is an important aspect that employers need to pay attention to.

Employees' job performance is greatly affected by their job stress level. This is because job stress has a direct impact on the quality of job performed by an employee. It is widely accepted that job stress has become a universal problem for employers and employees all around the world (Lambert et al., 2003). There are many job stressors that may affect employees' job performance, including the amount of work, job security, autonomy, role conflict, salary, lack of recognition and 'shift' work (Vijayan, 2017).

Job stress may also reduce employee motivation (Wani, 2013). This could be detrimental as only employees with high level of motivation show good performance in their workplace. Motivation has a significant impact on job performance because it serves as an important driving force for a person to perform a task (Noermijati \& Primasari, 2015). Employees' motivation level also determines the quality of their participation in their respective organizations (Barling et al, 2003). Hence, it is essential that employers provide appropriate motivation for their employees in order for them to show good job performance and ensure the success of the organization.

\subsection{Problem Statement}

The Royal Malaysian Police (PDRM) is responsible for law enforcement, order management and maintaining public safety to ensure district development and reduce crime rates (Cheah et al., 2018). The police force is one of the most stressed professions in public sector organizations around the world. It is a challenging career as police officers take great amount risks in their daily jobs and these can be detrimental to their health.

Law enforcement is one of the occupations where its employees work with various individuals from all walks of life (Kula \& Guler, 2014). According to Ivie and Garland (2011), law enforcers are often surrounded by burdens. Indeed, policing has been regarded as one of the most stressful professions due to nature of their job such as long working hours, organizational hierarchy and security issues (Aytac, 2015). 
Nevertheless, prolonged exposure to high job stress will not only affect police officers' physical and psychological health, but will also affect their job performance in terms of productivity and commitment. On the other hand, job performance of police officers is also influenced by their motivation. Motivated police officers will be happier to work and show good performance (Susan et al, 2012). Therefore, this study is intended to study the relationship between job performance, job stress and motivation of police officers

\subsection{Research Objectives}

i. Identify the influence of job stress on job performance of police officers

ii. Identify the influence of job stress on motivation of police officers

\subsection{Research Hypothesis}

i. $\quad \mathrm{H} 1$ : There is no significant effect of work stress on job performance.

ii. $\quad \mathrm{H} 2$ : There is no significant effect of work stress on job motivation.

\subsection{Importance of Research}

From the organizational perspective, the undertaken research implies improvement of police officers' job performance by enhancement of work motivation with job stress as a moderating factor.

\subsection{Literature Review}

\subsubsection{Job Performance}

Job performance is the assessment of how a person is performing in his work. Job performance describes what is done, how it is done and what results are achieved in a job. Thus, job performance can be used to review, examine and evaluate employee behaviour and performance in line with organizational goals and objectives. As mentioned earlier, the main criteria for the success of an organization are based on the performance of their employees. Employees with a high level of performance will have a high sense of competence, achievement and effectiveness in completing their tasks, thus ensuring the success of an organization.

\subsubsection{Job Stress}

Considerable amount of stress can motivate people to achieve their life goals. However, it becomes a challenge when they no longer be able to cope with overwhelming stress. Failure to address and manage stress in the early stages may lead to chronic health problems such as hypertension, heart disease, depression and anxiety. Job stress is a common issue at workplace. Job stress is defined as the harmful physical and emotional responses that occur when the requirements of the job do not match the capabilities, resources, or needs of employee (NIOSH, 1999). In general, many employees want to achieve self- and job satisfaction by performing well in their job. However, their occupation itself can place significant job stress and burden on the employee in the presence of factors such as large amount of work, deadlines and pressure from management which may be quite challenging. Thus, work and its related factors can cause a person to experience stress and eventually 


\section{Macrothink}

become less productive in workplace.

\subsubsection{Job Motivation}

Motivation is the state of mind of people which drives them to act in a particular way. Motivation is a capable of triggering and reinforcing a behaviour or action (Dobre, 2013). In terms of work, job performance is closely related to motivation level. Motivated employees are aligned with organizational goals and efforts can be easily focused towards achievement of those goals (Elangovan et al., 2010). Moreover, organizations with motivated employees are often more successful because employees will always perform tasks efficiently and find ways to improve their job performance (De Jong \& Den Hartog, 2007).

\subsubsection{Job Satisfaction}

Job satisfaction is the positive emotions and pleasurable feeling of employees due to their job experiences (Ćulibrk et al., 2018). It is a key element of work motivation, which determines employees' general behaviour in the organization. Job satisfaction has a direct impact on employees' effectiveness, efficiency, commitment and productivity. It is highly dependent on employees' working environment (Raziq \& Maulabakhsh, 2015). A good working environment including low work stress may contribute positively towards job satisfaction. This is because work stress has been found to have an adverse effect on employees' job satisfaction and job performance (Chao et al., 2015).

\subsubsection{Motivation Theory}

Herzberg's Motivation Theory model or Two Factor Theory states that there are two factors that can influence motivation in the workplace. In this regard, motivators are factors which can encourage employees to work harder while hygiene factors often make employees unmotivated if they are not present. Motivators such as money, achievements, recognition, responsibility, and work advancement are great source of job satisfaction (Sobaih \& Hasanein, 2020) and positively affects job satisfaction. On the other hand, hygiene factors negatively affect job satisfaction as they often be the source of dissatisfaction. These include working conditions such as salaries, relationships with colleagues, administrative policies, and supervision. Herzberg used this model to explain that an individual at work can be satisfied and dissatisfied at the same time as these two sets of factors work in separate sequences. Motivators need to be harmonized with hygiene factors to achieve job satisfaction at work (Al-Rahawi et al., 2020).

\section{Method}

\subsection{Sampling}

This quantitative study was conducted using survey methodology to collect data. A total of 341 samples were obtained using purposive sampling from the population of PDRM officers at the Federal Territory Police Headquarters. 


\section{Macrothink}

International Journal of Human Resource Studies

ISSN 2162-3058

2021, Vol. 11, No. 4S

\subsection{Instrumentation and Data Analysis}

A questionnaire with Likert-scales items was employed as instrument to collect data. For job performance', 18 items on a 5-point Likert scale were used to record respondents' scores ranging from 1-Rarely/Never to 5- Always/Often. For job stress, 'Occupational Stress Index' containing 46 items on a 5-point Likert scale was used with responses ranging from 1-Strongly Disagree to 5-Strongly Agree. For motivation, 'Extrinsic and Intrinsic Motives Work Scale' with 18 items on a 7-point Likert scale was used to obtain respondents' scores ranging from 1-Not Appropriate at All to 7-Appropriate and Accurate. Data from the completed questionnaire was then analyzed statistically with PLS-SEM software.

\section{Results}

\subsection{Sociodemographic Profile of Respondents}

Table 1. Sociodemographic profile of respondents

\begin{tabular}{|c|c|c|}
\hline Characteristics & Frequency & $\%$ \\
\hline \multicolumn{3}{|l|}{ Gender } \\
\hline Male & 277 & 81.2 \\
\hline Female & 64 & 18.8 \\
\hline \multicolumn{3}{|l|}{ Age } \\
\hline $20-30$ & 20 & 5.9 \\
\hline $31-40$ & 170 & 49.9 \\
\hline $41-50$ & 77 & 22.6 \\
\hline 51 and above & 74 & 21.7 \\
\hline \multicolumn{3}{|l|}{ Marital status } \\
\hline Single & 37 & 10.9 \\
\hline Married & 304 & 89.1 \\
\hline \multicolumn{3}{|l|}{ Education level } \\
\hline STPM/Diploma & 76 & 22.3 \\
\hline Bachelor degree & 163 & 47.8 \\
\hline Masters degree & 99 & 29.0 \\
\hline $\mathrm{PhD}$ & 3 & 0.9 \\
\hline \multicolumn{3}{|l|}{ Rank } \\
\hline INSP - ASP & 262 & 76.8 \\
\hline DSP - SUPT & 65 & 19.1 \\
\hline $\mathrm{ACP}-\mathrm{SAC}$ & 11 & 3.2 \\
\hline DCP and above & 3 & 0.9 \\
\hline \multicolumn{3}{|c|}{ Monthly income (RM) } \\
\hline $2500-4500$ & 51 & 15.0 \\
\hline $4501-6500$ & 161 & 47.2 \\
\hline $6501-8500$ & 79 & 23.2 \\
\hline 8501 and higher & 50 & 14.7 \\
\hline \multicolumn{3}{|c|}{ Length of service (years) } \\
\hline 10 or less & 80 & 23.5 \\
\hline $11-20$ & 134 & 39.3 \\
\hline $21-30$ & 64 & 18.8 \\
\hline 31 and more & 63 & 18.5 \\
\hline
\end{tabular}




\section{Macrothink}

International Journal of Human Resource Studies

ISSN 2162-3058

2021, Vol. 11, No. 4S

Majority of the study respondents were male $(81.2 \%)$, indicating that career as police officers is dominated by men over women. This could be because police officer is a job of choice for men following the need for physical fitness and high mental intelligence. Most of the respondents were aged between 31 to 40 years (49.9\%), followed by 41 to 50 years $(22.6 \%)$ and 51 years and above $(21.7 \%)$. Majority $(89.1 \%)$ of respondents were married and a total of $39.3 \%$ had served as a police officer for 11 to 20 years. In terms of education level, $47.8 \%$ respondents had a Bachelor's Degree, followed by Master's degree (29.0\%) and STPM / Certificate (22.3\%). Majority of the respondents held the rank of INSP to ASP (76.8\%), with monthly salary between RM 4501 to RM 6500. On overall, these findings indicate a high socio-economic level among the police officers.

\subsection{Descriptive Analysis of Job Stress, Job Performance and Job Motivation}

Table 3.2. Descriptive analysis

\begin{tabular}{llll}
\hline & Mean & SD & Level \\
\hline Job stress & 2.87 & 0.48 & Moderate \\
Job performance & 3.71 & 0.56 & High \\
Job motivation & 3.76 & 0.62 & High \\
\hline
\end{tabular}

Job stress of police officers was found to be at a moderate level. Nevertheless, past studies have noted that even a moderately high work stress may cause police officers to be unable to control their emotions and associate it with unpleasant attitudes.

\subsection{Relationship Between Job Stress, Job Performance and Job Motivation}

Table 3. Relationship between variables

\begin{tabular}{lcccccc}
\hline Path & $\boldsymbol{\beta}$ & Mean & SD & t & 95\% CI & p \\
\hline Job stress $\square$ Job performance & -0.458 & -0.453 & 0.056 & 8.152 & $-0.540,-0.358$ & $<0.00$ \\
& & & & & & $<$ \\
Job stress $\square$ Job motivation & -0.311 & -0.331 & 0.081 & 3.846 & $-0.455,-0.208$ & $<0.00$ \\
& & & & & & \\
\hline
\end{tabular}

Path coefficient analysis was conducted to measures the direct and indirect relationship among variables. There was a negative relationship between job stress and job performance with $\beta=0.458,95 \% \mathrm{CI}=0.540,0.358, \mathrm{t}$-value $=8.152$, while job stress also showed $\mathrm{a}$ negative relationship with job motivation with $\beta=0.311,95 \% \mathrm{CI}=0.455,0.208, \mathrm{t}$-value $=$ 3.846. Therefore, hypothesis $\mathrm{H} 1$ which states that there is no significant effect of job stress on job performance was rejected. Additionally, hypothesis $\mathrm{H} 2$ which states that there is no significant effect of job stress on job motivation was also rejected.

\section{Discussion}

There had been incidences of suicide, murder and mental health problems among police officers with reported job stress. This could be due to the fact that job stress is a complex problem involving workload, job security and work environment (Yozgat et al., 2013). In this 
regard, policing is a profession full of stress and the failure to deal with the pressure may adversely affect the job performance of police officers (Prysmakova \& Vandenabeele, 2020).

Study also shown a high level of job performance among the police officers. This could be an impact of the various strategic plans implemented by PDRM to achieve optimum resilience and work performance (Razali et al., 2021), such as the Police Strategic Plan 2015-2020 and Police Integrity Plan 2016-2020. Police officers who are more resilient would have better morale, strength and dedication in improving their work performance (Giessing et al., 2019). Moreover, it is crucial to ensure high job performance of police officers because of its huge impact on organizational image and effectiveness. (Stoyanova \& Iiiev, 2017).

In this study, the level of job motivation was found to be high among police officers. Job motivation is an important indicator of emotional and psychological health of employees (Hünefeld et al., 2020). Job motivation is considered key for organizations, in understanding employee well-being, commitment, productivity, and job performance (Abdullah et al., 2020; DiPietro et al., 2020).

The results of this study are in line with Mohd Shah Rizan (2015) which showed that high levels of work stress affect police officers' work performance. It has been suggested that three important aspects of stress, namely role ambiguity, role conflict and job control in organizations significantly affects job performance of police officers. Previous researchers have also highlighted other factors which are commonly associated to job stress including insufficient job-related knowledge (Rahim et al., 2018), overly high work demands and workload, and unsafe work environment (Sandrin et al., 2019; Knight et al., 2019; Patterson et al., 2018). Furthermore, problems in organizations and operations may also contribute towards job stress among police officers (Queiros et al., 2020; Li et al., 2019).

This study shows that there is a significant and negative relationship between job stress and job motivation. Motivation towards job is a personal factor which may affect the way an employee deals with job related stress. Apparently, motivation factors within organizational context may also influence the extent to which police officers experience stress and stress-related symptoms (Sandrin et al., 2019; Baljoon et al., 2018; Prysmakova \& Vandenabeele, 2020). This explains why some police officers may experience more stress at work and physical symptoms than the others. Police officers 'experience of chronic stress makes them particularly vulnerable to high blood pressure, stomach ulcers, respiratory problems, skin problems, and migraines (Li et al., 2019; Queiros et al., 2020; Sherwood et al., 2019). Police stress is also associated with adverse consequences for police organizations, including intention to leave employment for another career, absenteeism, early retirement, and psychological burnout that are highly correlated with their level of motivation (Porumbescu et al., 2019; Queirós et al., 2020).

The study found that there is significant effect of job stress on job performance; and job stress on job motivation. A negative relationship between job stress and job performance indicates that high job stress may reduce job performance of police officers. Similarly, the negative relationship between job stress and job motivation indicates that high job stress may lower job motivation among the police officers. Nevertheless, the higher is the job motivation, the 
better the police officers may deal with their job stress.

\section{Acknowledgement}

The authors wish to thank all the Royal Malaysia Police officers who participated in this study.

\section{References}

Abdullah, F. N. (2018). Factors influencing employee performance. Student Thesis. Universiti Mara Malaysia.

Alrawahi, S., Fransson, S., Altouby, S. S., Alwahaibi, N., \& Brommels, M. (2020). The application of Herzberg's two-factor theory of motivation to job satisfaction in clinical laboratories in Omani hospitals, Heliyon, 6(9). https://doi.org/10.1016/j.heliyon.2020.e04829

Aytac, T. (2015). The Effect of Gender on Teachers' Job Satisfaction: A Meta-analysis. The Anthropologist, 20(3), 385-396. https://doi.org/10.1080/09720073.2015.11891742

Baljoon, R. A., Banjar, H. E., \& Banakhar, M. A. (2018). Nurses' work motivation and the factors affecting It: A scoping review. International Journal of Nursing \& Clinical Practices, 5(1). https://doi.org/10.15344/2394-4978/2018/277

Barling, J., Kelloway, E. K., \& Iverson, R. D. (2003). High-quality work, job satisfaction, and occupational injuries. Journal of Applied Psychology, 88(2), 276-283. https://doi.org/10.1037/0021-9010.88.2.276

Chao, M-C, Jou, R-C, Liao, C-C, Kuo, C-W. (2015).Workplace Stress, Job Satisfaction, Job Performance, and Turnover Intention of Health Care Workers in Rural Taiwan. Asia Pacific Journal of Public Health, 27(2), NP1827-NP1836. https://doi.org/10.1177/1010539513506604

Cheah, P. K., Unnithan, N. P., \& Suppiah, S. (2018). Role reflections of police reservists: a study of volunteer reserve officers in Malaysia. Policing: An International Journal, 41(6), 813-827. https://doi.org/10.1108/PIJPSM-05-2017-0065

Chen, Y-F. (2009). Job Stress and Performance: A Study of Police Officers in Central Taiwan. Social Behavior and Personality: an international journal, 37, 1341-1356. https://doi.org/10.2224/sbp.2009.37.10.1341

Chen, Z. (2018). Job satisfaction among frontline police officers in China: The role of demographic, work-related, organizational and social factors. Psychology, Crime \& Law, 24(9), 895-914. https://doi.org/10.1080/1068316X.2018.1442835

Ćulibrk, J., Delić, M., Mitrović, S., \& Ćulibrk, D. (2018). Job Satisfaction, Organizational Commitment and Job Involvement: The Mediating Role of Job Involvement. Frontiers in psychology, 9, 132. https://doi.org/10.3389/fpsyg.2018.00132 


\section{Ml Macrothink}

International Journal of Human Resource Studies

ISSN 2162-3058

2021, Vol. 11, No. 4S

De Jong, J. P., \& Den Hartog, D. N. (2007). How Leaders Influence Employees' Innovative Behaviour. European Journal of Innovation Management, 10, 41-64. https://doi.org/10.1108/14601060710720546

DiPietro, R., Moreo, A., \& Cain, L. (2020). Well-being, affective commitment and job satisfaction: influences on turnover intentions in casual dining employees. Journal of $\begin{array}{lllll}\text { Hospitality } \quad \text { Marketing } \quad \text { M } & \text { 1-25. }\end{array}$ https://doi.org/10.1080/19368623.2019.1605956

Dobre, O. I. (2013). Employee motivation and organizational performance. Review of Applied Socio-Economic Research, 5(1), 53.

Elangovan, A. R., Pinder, C. C., \& McLean, M. (2010). Callings and organizational behavior. Journal of Vocational Behavior, 76(3), 428-440. https://doi.org/10.1016/j.jvb.2009.10.009

Giessing, L., Frenkel, M. O., Zinner, C., Rummel, J., Nieuwenhuys, A., Kasperk, C., ..., \& Plessner, H. (2019). Effects of coping-related traits and psychophysiological stress responses on police recruits' shooting behavior in reality-based scenarios. Frontiers in psychology, 10, 1523. https://doi.org/10.3389/fpsyg.2019.01523

Hünefeld, L., Gerstenberg, S., \& Hüffmeier, J. (2020) Job satisfaction and mental health of temporary agency workers in Europe: a systematic review and research agenda, Work \& Stress, 34(1), 82-110. https://doi.org/10.1080/02678373.2019.1567619

Ivie, D., \& Garland, B. (2011). Stress and burnout in policing: Does military experience matter? Policing-an International Journal of Police Strategies \& Management - POLICING, 34, 49-66. https://doi.org/10.1108/13639511111106605

Jamal, M. (2016). Job stress and job performance relationship in challenge-hindrance model of stress: An empirical examination in the Middle East, Pakistan Journal of Commerce and Social Sciences, 10(3), 404-418.

Knight, C., Patterson, M., \& Dawson, J. (2019). Work engagement interventions can be effective: a systematic review. European Journal of Work and Organizational Psychology, 28(3), 348-372. https://doi.org/10.1080/1359432X.2019.1588887

Kula, S. (2017). Occupational stress, supervisor support, job satisfaction, and work-related burnout: perceptions of Turkish National Police (TNP) members. Police Practice and Research, 18(2), 146-159. https://doi.org/10.1080/15614263.2016.1250630

Lambert, V., Lambert, C., \& Yamase, H. (2003). Psychological hardiness, workplace stress and related stress reduction strategies. Nursing \& Health sciences, 5, 181-184. https://doi.org/10.1046/j.1442-2018.2003.00150.x

Li, J. C., Cheung, J. C., \& Sun, I. Y. (2019). The impact of job and family factors on work stress and engagement among Hong Kong police officers. Policing: An International Journal. https://doi.org/10.1108/PIJPSM-01-2018-0015 
Mohd Shah Rizan, M. R. (2015). The influence of job stress factors toward job performance among Royal Malaysian Police at Kuala Lumpur. Master Thesis. Universiti Teknologi Malaysia.

National Institute of Occupational Safety and Health (NIOSH) (1999). Available online from: www.cdc.gov/niosh/docs/99-101

Noermijati, \& Primasari, D. (2015). The effect of job stress and job motivation on employees performance through job satisfaction (A study at PT. Jasa Marga (Persero) Tbk. Surabaya Gempol branch ). Journal of Economics, Business and Accountancy Ventura, 18(1), 231-240. https://doi.org/10.14414/jebav.v18i2.450

Patterson, P. D., Weaver, M. D., Fabio, A., Teasley, E. M., Renn, M. L., Curtis, B. R., \& Higgins, J. S. (2018). Reliability and validity of survey instruments to measure work-related fatigue in the emergency medical services setting: a systematic review. Prehospital Emergency Care, 22(sup1), 17-27. https://doi.org/10.1080/10903127.2017.1376134

Porumbescu, G. A., Neshkova, M. I., \& Huntoon, M. (2019). The effects of police performance on agency trustworthiness and citizen participation. Public Management Review, 21(2), 212-237. https://doi.org/10.1080/14719037.2018.1473473

Prysmakova, P., \& Vandenabeele, W. (2020). Enjoying police duties: Public service motivation and job satisfaction. Journal of police and criminal psychology, 35(3), 304-317. https://doi.org/10.1007/s11896-019-09324-7

Queirós, C., Passos, F., Bártolo, A., Marques, A. J., da Silva, C. F., \& Pereira, A. (2020). Burnout and stress measurement in police officers: Literature review and a study with the operational police stress questionnaire. Frontiers in psychology, 11, 587. https://doi.org/10.3389/fpsyg.2020.00587

Rahim, M. A., Psenicka, C., Nicolopoulos, A. G., \& Antonioni, D. (2018). Relationships of leader power to subordinates' styles of handling conflict and organizational commitment: A comparison between the US and Greece. In Current topics in management (pp. 187-204). Routledge. https://doi.org/10.4324/9780203793961-9

Razali, F., Rami, A. A. M., Nazuri, N. S., \& Suhaimi, S. S. A. (2021). Relationship Between Leadership, Resilience, and Competence Amongst Police Officers in Klang Valley, Malaysia. Asian Social Science, 17(11), 39-47. https://doi.org/10.5539/ass.v17n11p39

Raziq, A., \& Maulabakhsh, R. (2015). Impact of Working Environment on Job Satisfaction, $\begin{array}{lllll}\text { Procedia Economics } & \text { Finance, } & 23,725 .\end{array}$ https://doi.org/10.1016/S2212-5671(15)00524-9

Sandrin, É., Gillet, N., Fernet, C., Leloup, M., \& Depin-Rouault, C. (2019). Effects of motivation and workload on firefighters' perceived health, stress, and performance. Stress and Health, 35(4), 447-456. https://doi.org/10.1002/smi.2873

Sherwood, L., Hegarty, S., Vallières, F., Hyland, P., Murphy, J., Fitzgerald, G., \& Reid, T. (2019). Identifying the key risk factors for adverse psychological outcomes among police 
officers: a systematic literature review. Journal of traumatic stress, 32(5), 688-700. https://doi.org/10.1002/jts.22431

Sobaih, A. E. E., \& Hasanein, A. M. (2020) Herzberg's theory of motivation and job satisfaction: Does it work for hotel industry in developing countries?, Journal of Human $\begin{array}{lllll}\text { Resources in Hospitality } \quad \text { \& } & \text { Tourism, } & 19(3), & 319-343 .\end{array}$ https://doi.org/10.1080/15332845.2020.1737768

Stoyanova, T., \& Iliev, I. (2017). Employee Engagement Factor for Organizational Excellence. International Journal of Business and Economic Sciences Applied Research, 10, 23-29. https://doi.org/10.25103/ijbesar.101.03

Susan, W. M., Gaikure, R. W., Kiraithe, E. K., \& Waititu, A. G. (2015) Influence of Motivation on Performance in the Public Security Sector with a Focus to the Police Force in Nairobi, Kenya International Journal of Business and Social Science, 3(23),195-204.

Vijayan, M. (2018). Impact of Job Stress on Employees' Job Performance In Aavin, Coimbatore. Journal of Organisation \& Human Behaviour, 6(3), 21-29.

Wani, D. S. (2013). Job stress and its impact on employee motivation : a study of a select commercial bank. International Journal of Business and Management Invention, 2(3), 13-18.

Yozgat, U., Yurtkoru, S., \& Bilginoğlu, E. (2013). Job Stress and Job Performance Among Employees in Public Sector in Istanbul: Examining the Moderating Role of Emotional Intelligence. Procedia - Social and Behavioral Sciences, 75, 518-524. https://doi.org/10.1016/j.sbspro.2013.04.056

\section{Copyright Disclaimer}

Copyright for this article is retained by the author(s), with first publication rights granted to the journal.

This is an open-access article distributed under the terms and conditions of the Creative Commons Attribution license (http://creativecommons.org/licenses/by/4.0/). 